\title{
The past century of coral bleaching in the Saudi Arabian central Red Sea
}

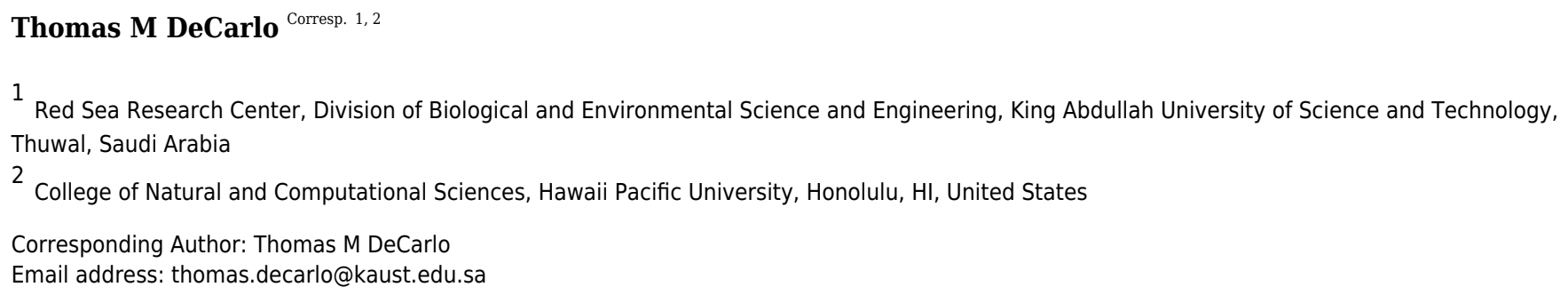

Accurate knowledge of the spatial and temporal patterns of coral bleaching is essential both for understanding how coral reef ecosystems are changing today and forecasting their future states. Yet, in many regions of the world, the history of bleaching is poorly known, especially prior to the late $20^{\text {th }}$ century. Here, we use the information preserved within skeleton cores of long-lived Porites corals to reconstruct the past century of bleaching events in the Saudi Arabian central Red Sea. In these cores, skeletal "stress bands"-indicative of past bleaching-captured known bleaching events that occurred in 1998 and 2010, but also revealed evidence of previously unknown bleaching events in 1931, 1978, and 1982. However, these earlier events affected a significantly lesser proportion of corals than 1998 and 2010. Therefore, coral bleaching may have occurred in the central Red Sea earlier than previously recognized, but the frequency and severity of bleaching events since 1998 on nearshore reefs is unprecedented over the past century. Conversely, corals living on mid- to outer-shelf reefs have not been equally susceptible to bleaching as their nearshore counterparts, since stress bands were five times more prevalent nearshore. Whether this pattern of susceptible nearshore reefs and resistant outer-shelf reefs continues in the future remains a key question in forecasting coral reef futures in this region. 


\section{The past century of coral bleaching in the Saudi Arabian central Red Sea}

2

3 Thomas M. DeCarlo ${ }^{1,2 *}$

4

$5{ }^{1}$ Red Sea Research Center, Division of Biological and Environmental Science and Engineering, 6 King Abdullah University of Science and Technology, Thuwal, Saudi Arabia

7 2Present address: College of Natural and Computational Sciences, Hawai'i Pacific University, 8 Honolulu, HI 96744, USA

$9 *$ corresponding author: tdecarlo@hpu.edu

10

\section{Abstract}

12 Accurate knowledge of the spatial and temporal patterns of coral bleaching is essential both for understanding how coral reef ecosystems are changing today and forecasting their future states.

14 Yet, in many regions of the world, the history of bleaching is poorly known, especially prior to 15 the late $20^{\text {th }}$ century. Here, I use the information preserved within skeleton cores of long-lived 16 Porites corals to reconstruct the past century of bleaching events in the Saudi Arabian central

17 Red Sea. In these cores, skeletal "stress bands" — indicative of past bleaching — captured known

18 bleaching events that occurred in 1998 and 2010, but also revealed evidence of previously 19 unknown bleaching events in 1931, 1978, and 1982. However, these earlier events affected a 20 significantly lesser proportion of corals than 1998 and 2010. Therefore, coral bleaching may

21 have occurred in the central Red Sea earlier than previously recognized, but the frequency and

22 severity of bleaching events since 1998 on nearshore reefs is unprecedented over the past

23 century. Conversely, corals living on mid- to outer-shelf reefs have not been equally susceptible 
24 to bleaching as their nearshore counterparts, since stress bands were five times more prevalent

25 nearshore. Whether this pattern of susceptible nearshore reefs and resistant outer-shelf reefs

26 continues in the future remains a key question in forecasting coral reef futures in this region.

27

\section{Introduction}

29

Reef-building corals thrive in the warm waters of the tropical oceans. Yet, despite their affinity

30

31

32

for warm regions, anomalous increases in temperature of as little as $1{ }^{\circ} \mathrm{C}$ can damage the symbiosis between the coral host and the photosynthetic algae that inhabit the host's tissues.

When summertime temperatures exceed typical levels, the endosymbiont photosystem is impaired and begins to produce more reactive oxygen species than the coral can tolerate, leading to the expulsion of the symbionts (Lesser, 1997; Baker, Glynn \& Riegl, 2008). Without their pigmented symbionts, corals turn white as their calcium carbonate skeletons become visible through their translucent tissues. Since the symbionts provide most of the energy that the coral needs to survive, bleaching causes reduced growth, fecundity, and lipid content, eventually leading to mortality if bleaching is prolonged (Mendes \& Woodley, 2002; Grottoli, Rodrigues \& Juarez, 2004). Coral bleaching was first observed by scientists in 1929 during the Great Barrier Reef Expedition on a shallow reef flat when calm weather led to localized heating of reef waters (Yonge \& Nicholls, 1931). Other small-scale bleaching events were later observed due to localized disturbances such as freshwater (Goreau, 1964) or cold stress (Muscatine, Grossman \& Doino, 1991; Saxby, Dennison \& Hoegh-Guldberg, 2003; Hoegh-Guldberg \& Fine, 2004; PazGarcía, Balart \& García-De-Léon, 2012), with heat-induced, ocean basin-scale mass coral bleaching first observed in 1982/1983 (Glynn, 1983, 1993; Coffroth, Lasker \& Oliver, 1990), although other events may have occurred earlier (Cavole \& DeCarlo, 2020). Since 1982, global 
47 mass coral bleaching events have increased in frequency, most likely caused by more common

48 heat stress due to global warming (Hughes et al., 2017, 2018; Sully et al., 2019).

The Red Sea is lined by thousands of kilometers of near-continuous, shallow-water coral

50 reefs (Rowlands et al., 2012; Churchill et al., 2019). These reefs are mostly restricted to the continental shelf, ranging from fringing reefs along the coast to knoll reef platforms dotting the shelf until the slope break (Montaggioni et al., 1986). Although the Red Sea is one of the warmest coral reef regions with summertime temperatures in the central and southern Red Sea

54 routinely reaching $33{ }^{\circ} \mathrm{C}$, corals living there are not necessarily more prone to bleaching than 55 conspecifics in cooler regions because they have acclimatized or adapted to their local environment. Experimental evidence suggests that corals in the far northern Red Sea, however, are currently living as much as $4{ }^{\circ} \mathrm{C}$ below their thermal maximum, potentially a result of the south to north (i.e., warmer to cooler) migration of corals following the most recent glaciation (Fine, Gildor \& Genin, 2013; Krueger et al., 2017). This has led to suggestions that the far northern Red Sea could be a climate change refuge for at least some species (Fine, Gildor \&

61 Genin, 2013; Kleinhaus et al., 2020), a hypothesis which—so far-has proven true since no 62 bleaching has been observed there (Osman et al., 2018). Conversely, the central Red Sea has experienced several bleaching events, which were directly observed in 1998 (Devantier \&

64 Pilcher, 2000; Devantier et al., 2000), 2010 (Furby, Bouwmeester \& Berumen, 2013; Pineda et al., 2013), and 2015 (Monroe et al., 2018). Yet, there were few systematic reef surveys prior to 1998 in the Red Sea (but see Antonius, 1988), leaving gaps in our knowledge of whether earlier bleaching events occurred in this region. with the global average for coral reef regions (Lough, Anderson \& Hughes, 2018), the warming 
70 trend has been punctuated by sporadic episodes of anomalously high temperatures and pulses of

71 rapid warming (Raitsos et al., 2011; Krokos et al., 2019). In particular, two relatively warm

72 intervals, one centered around the 1930s and the other around the 1970s, are superimposed on

73 the centennial warming trend (Krokos et al., 2019). These warm periods result from the

74 combination of climate teleconnections in the north Atlantic and equatorial Pacific (Karnauskas

75 \& Jones, 2018; Krokos et al., 2019). Critically, since systematic surveys of coral health had not

76 yet begun in the Red Sea, we do not know if these earlier warm periods were associated with

77 coral bleaching events, or alternatively, if the recent bleaching events in the central Red Sea are

78 unprecedented. Here, I use the stress history preserved within the skeletons of long-lived Porites

79 spp. corals from the Saudi Arabian central Red Sea to reconstruct bleaching events over the past

80 century, and I compare the presence of stress bands to a variety of ocean temperature and wind

81 datasets.

82

83 Methods

84 Bleaching histories from coral skeletal cores

85 Between August 2019 and January 2020, I drilled twenty-two skeletal cores from massive

86 Porites spp. coral colonies near the Thuwal region of the central Red Sea (Fig. 1). The primary

87 study location was a nearshore reef called Abu Shosha (11 cores), but I also collected cores at

88 reefs across the shelf (1-2 cores per reef, 11 total cores). The cores were drilled downwards from

89 the top of each colony using a pneumatic drill with either 3- or 5-cm diameter diamond-tipped

90 bits. All cores were rinsed several times with fresh water, then with pure ethanol, and air dried.

91 To visualize density banding patterns within the cores, I scanned them with computerized

92 tomography (CT) using a General Electric BrightSpeed machine. Scan settings included $100 \mathrm{kV}$ 
93 voltage, $9.6 \mathrm{~cm}$ field of view, and $1.25 \mathrm{~mm}$ pixel spacing (i.e., resolution). The CT scans were 94 visualized using Osirix software, which enabled me to cut digital slices 3-5 $\mathrm{mm}$ thick along the 95 primary growth axes (Carilli et al., 2009; Cantin et al., 2010). Annual density bands and 96 anomalous high-density "stress bands" were identified visually based on the banding pattern of 97 each coral. Most of the cores had clear annual banding patterns with little ambiguity. Stress band 98 identifications were based on their previously described appearances as sharply-defined bands 99 that are anomalous relative to the regular annual banding pattern (Hudson et al., 1976; Carilli et 100 al., 2009; Cantin \& Lough, 2014; Barkley \& Cohen, 2016; DeCarlo et al., 2017, 2019; Barkley et 101 al., 2018). The cores were not identified to species level, however there are only three possible 102 species (lutea, lobata, and solida) with massive growth form in this region (Terraneo et al., 103 2019), and a previous study found no effect of species on stress band prevalence (DeCarlo et al., 104 2020).

I followed the statistical approach of Hendy et al. (2003) to compare the prevalence of 106 stress bands among years. Specifically, I calculated the probability of finding, per year, the number of observed stress bands or fewer based on bleaching events affecting a certain number 108 of Porites corals. Determining these probabilities enables statistical testing of severity between 109 events (e.g., whether the number of observed stress bands in a given year is statistical different

110 from another year, or from zero). These calculations require three inputs: the number of 111 replicates (i.e., the number of cores covering each year), the number of stress bands observed per 112 year, and the severity of hypothetical bleaching events. Since the latter is arbitrary, I repeated the 113 calculations using two severity levels: the proportion of Porites that were bleached on Abu 114 Shosha $(\sim 1 / 3)$ during underwater surveys in 2015 (Monroe et al., 2018), and the maximum 115 proportion of stress bands observed in any one year (see Results). 
117 Climate data

118 I used four sea surface temperature (SST) datasets that differ in temporal coverage and spatial

119 resolution. Two daily satellite-based products, Optimum Interpolation SST (OI-SSTv2)

120 (Reynolds et al., 2007; Banzon et al., 2016) and Coral Reef Watch's CoralTemp (CRW) (Liu et

121 al., 2014) cover from present back until 1982 and 1985, at spatial resolutions of $\sim 25 \mathrm{~km}$ and $\sim 5$

$122 \mathrm{~km}$, respectively. To assess temperatures prior to the satellite era, I used HadISST (Rayner et al.,

123 2003) and ERSSTv5 (Huang et al., 2017), which are both monthly and have spatial resolutions of

$1241^{\circ}(\sim 110 \mathrm{~km})$ and $2^{\circ}(\sim 220 \mathrm{~km})$, respectively. I calculated degree heating weeks (DHW), a

125 metric of heat stress that incorporates both the magnitude and duration of SST anomalies

126 exceeding the maximum monthly mean (MMM) (Liu, Strong \& Skirving, 2003), separately for

127 each dataset. For the two monthly datasets (HadISST and ERSSTv5), I adjusted the typical

128 DHW formula such that DHW begin to accumulate as soon as SST exceeds the MMM, rather

129 than requiring SST to exceed the MMM by $1{ }^{\circ} \mathrm{C}$. This was done because it is rare that the mean

130 SST of an entire month is $1{ }^{\circ} \mathrm{C}$ greater than the MMM (occurring only once for each dataset

131 between 1930 and 2019). Thus, the magnitudes of DHW calculated from HadISST and

132 ERSSTv5 are not directly akin to those of OI-SSTv2 and CRW, although relative differences

133 between years are comparable. For all datasets, I extracted the time series of the single grid-box

134 closest to our primary study site, Abu Shosha. Finally, for each SST dataset, I calculated the

135 maximum DHW that occurred per year for comparison to bleaching histories.

136 To assess the quantity of shipboard observations upon which HadISST and ERSSTv5 are

137 based during the pre-satellite era, I downloaded SST measurement metadata from the

138 International Comprehensive Ocean-Atmosphere Data Set (ICOADS3.0.0). I counted the number 
139 of observations in ICOADS corresponding to select bleaching years that fell within the HadISST

140 and ERSSTv5 grid-boxes nearest to Abu Shosha.

141 Wind speed data were acquired from the European Centre for Medium-Range Weather

142 Forecasts ERA5 reanalysis product (Copernicus, 2017). The data were downloaded as monthly

143 means at 31-km resolution covering 1979-2019, and the average August-September wind speed

144 anomalies were calculated per year for the grid-box nearest to Abu Shosha. August and

145 September were selected because these are the months when coral bleaching has been observed

146 in this region (Devantier \& Pilcher, 2000; Pineda et al., 2013; Monroe et al., 2018).

147 Photosynthetically active radiation (PAR) data were acquired from the moderate

148 resolution imaging spectroradiometer (MODIS) onboard the Terra satellite (2000-2018) and

149 from SeaWIFS (1998-1999) (Frouin, Franz \& Werdell, 2002). Like the wind data, I averaged the 150 August-September PAR anomalies per year for the grid-box nearest to Abu Shosha.

152 Results

153 The oldest observable bands in the coral skeletal cores from Abu Shosha ranged from 1917 to 1541986 with a median age of 1966 (Fig. 2), and those in cores from outside of Abu Shosha ranged 155 from 1907 to 2010 with a median age of 1968 (Fig. 3). In total, I counted 1,244 annual bands. At 156 Abu Shosha, I identified high-density stress bands in 2015 ( $1 / 11$ cores), 2010 (8/11 cores), 1998 157 (8/11 cores), 1982 (3/10 cores), 1978 (1/10 cores), and 1931 (1/2 cores) (Fig. 2). Only one core 158 (K15) had no stress bands in any year. Most stress bands were distinct high-density anomalies, 159 but their appearance varied among cores. For example, the 2010 stress bands in cores K24 and $160 \mathrm{~K} 2$ were the most obvious because both the absolute density of the stress band, and the sharpness 161 of the density gradient leading into the stress band, were exceptional relative to the rest of the 
162 core. Most other identified stress bands fit within these same criteria, but with weaker anomalies

163 than K24 and K2. Conversely, some stress bands (e.g., those in core K1) were identified based

164 on anomalies to the normal banding pattern, but without exceptionally high density. Both the

1651998 and 2010 stress bands in core K1 are characterized by distinct, thin bands that disrupt the

166 regular, broad annual bands. Although this type of stress band was rare in the dataset, similar

167 stress bands have been linked to directly-observed bleaching in other studies (DeCarlo \& Cohen,

168 2017). In a few cases, stress bands appeared to result in multi-annual changes in density or

169 banding patterns (e.g., K20 after 1998, and K13 after 1982). Outside of Abu Shosha, I found

170 only three stress bands among the 11 cores (two of which were in the same core), corresponding

171 to 1948 , 1978, and 2010 (Fig. 3). Details of all coral coring locations, as well as age and stress

172 bands results, and listed in Supplemental Table S1.

173 I calculated the probability of finding the observed number of stress bands or fewer for

174 each year of the two time-series (Abu Shosha, and outside of Abu Shosha). These calculations

175 were performed for a bleaching event affecting either 1/3 (as observed in benthic surveys of Abu

176 Shosha in 2015) or 8/11 (the number of stress bands identified in Abu Shosha corals during 1998

177 and 2010) of Porites colonies (Fig. 4). At Abu Shosha, I can exclude (with at least 95\%

178 confidence) that a comparable event to 1998/2010 occurred between 1934-2019 (Fig. 4A). Even

179 though stress bands were also present in 1978, 1982, and 2015, the number of cores with stress

180 bands in these years relative to the total number of cores was low enough that I could exclude an

181 event affecting at least 8 out of 11 Porites. Conversely, even though only one stress band was

182 associated with 1931, I cannot exclude that an event equivalent to 1998/2010 occurred in this

183 year due to the small sample size. Detecting an event affecting 1/3 of Porites requires greater

184 statistical power, and all years prior to 1970 cannot be excluded due to sample size. Additionally, 
185 based on stress band counts, I cannot exclude with 95\% confidence that bleaching in 1978, 1982, 186 or 2015 affected 1/3 or fewer of Porites colonies.

Outside of Abu Shosha, cores were from younger corals, on average, compared to Abu

188 Shosha, which limits the statistical power (Fig. 4B). Nevertheless, it is clear that the 1998 and 1892010 events that affected most Porites at Abu Shosha did not similarly affect other reefs, and I 190 can exclude that there were any events affecting 8 out of 11 Porites since 1949 . The 2010 and 1911978 stress bands found in cores K9 and K6, respectively, suggest that these bleaching events 192 did have at least some influence on corals outside of Abu Shosha, though. Conversely, the 1948 193 stress band in core K6 is not replicated in either the two other cores from outside Abu Shosha, or 194 in any of the four Abu Shosha cores, that extend that far back in time.

195 The four SST datasets used here show some similarities in heat stress during overlapping 196 years, but with key differences (Fig. 5). According to HadISST, the greatest DHW was reached 197 in 1931 (6.0 ${ }^{\circ} \mathrm{C}$-weeks), followed by 1998 (5.4 ${ }^{\circ} \mathrm{C}$-weeks) (Fig. 5A). However, 1978 and 1982 198 had no heat stress, and DHW in 2010 and 2015 were lower than several other years without 199 bleaching or stress bands. Conversely, ERSSTv5 shows only modest heat stress in $1931\left(2.8^{\circ} \mathrm{C}\right.$ 200 weeks) and 1998 (3.6 ${ }^{\circ} \mathrm{C}$-weeks), but much higher DHW in 2010 (9.5 ${ }^{\circ} \mathrm{C}$-weeks) and 2015 (8.9 $201{ }^{\circ} \mathrm{C}$-weeks). Similar to HadISST, there is no heat stress in ERSSTv5 during 1978 or 1982, and 202 there are several years with relatively high heat stress $\left(>4^{\circ} \mathrm{C}\right.$-weeks $)$ but without any evidence of 203 bleaching (e.g., 1941, 1957, 1963, 2001, 2006, 2017). Higher-resolution satellite SST datasets 204 (OI-SSTv2 and CRW) likewise show some agreement, but also key disparities in certain years 205 (Fig. 5B). For example, both OI-SSTv2 and CRW show no heat stress in 1982, nearly the same 206 DHW in 1998 (4.6 and $4.4^{\circ} \mathrm{C}$-weeks, respectively), and relatively low DHW in 2015. However, 207 the two depart during 2010, when OI-SSTv2 shows only $0.5^{\circ} \mathrm{C}$-weeks while CRW reached its 
208 highest DHW for this location of $5.3{ }^{\circ} \mathrm{C}$-weeks. During 2010, CRW displays highest DHW 209 nearshore (e.g., Abu Shosha), but with at least $3{ }^{\circ} \mathrm{C}$-weeks on the mid- to outer-shelf reefs (Fig.

210 6). Thus, even though the lower spatial resolution of OI-SSTv2 means that it would average

211 some of these spatial differences of DHW (Fig. 7D), this alone cannot explain the full difference

212 between the two datasets. Overall, the correlation $\left(\mathrm{r}^{2}\right)$ between DHW calculated with the two

213 longer-term datasets that are based primarily on shipboard measurements is only 0.16 , and that

214 between the two satellite-based datasets is even worse (0.13) (Fig. 4).

215 During August and September of 1931, there were 544 shipboard measurements in the 216 central Red Sea, 274 of which were located within the ERSSTv5 grid-box, and only 1 of which

217 was located within the HadISST grid-box (Fig. 7). By 1982, these numbers increased to 863,

218535 , and 26, respectively. Finally, in 1998, the sampling intensity was even greater, with 4,644

219 measurements in the central Red Sea, 2,466 in the ERSSTv5 grid-box, and 742 measurements in 220 the HadISST grid-box.

221 Wind speeds during August and September of years with observed bleaching or stress

222 bands on Abu Shosha were all anomalously low, although not exceptionally so (Fig. 8A). The

223 lowest wind speeds between 1979 and 2018 occurred in 2003, followed by 1982 . The years of

224 highest PAR were 1998, 2002, and 2004 (Fig. 8B). Although the bleaching year of 2010-like 225 1998 - was also associated with a positive PAR anomaly, PAR during 2015 was unusually low.

226

\section{Discussion}

228 Scientists directly observed and reported coral bleaching in the central Red Sea during August-

229 September of 1998, 2010, and 2015 (Devantier \& Pilcher, 2000; Furby, Bouwmeester \&

230 Berumen, 2013; Pineda et al., 2013; Monroe et al., 2018). The current knowledge, which has 
231 been incorporated in a global assessment of spatial and temporal patterns of bleaching, is that no

232 other bleaching events have occurred in this region, at least since 1980 (Hughes et al., 2018). It

233 should be noted that coral disease surveys began near Jeddah ( $100 \mathrm{~km}$ to the south) in 1982 and

234 continued for several years (Antonius, 1988). In these surveys, "frequent" coral bleaching was

235 observed near Jeddah (13-25 colonies per 30-minute survey), although the year(s) in which this

236 occurred is not stated (Antonius, 1988). Since few colonies were affected and the author

237 attributed the bleaching near Jeddah to a combination of pollution and freshwater run-off (albeit

238 with no direct evidence to support this claim), subsequent studies have not considered these early

239 observations to represent heat-induced coral bleaching (Furby, Bouwmeester \& Berumen, 2013;

240 Hughes et al., 2018; Berumen et al., 2019).

241 In this study, stress bands in long-lived Porites corals are broadly consistent with this

242 current knowledge, except that I also found three stress bands corresponding to 1982 at a

243 nearshore reef, Abu Shosha (Fig. 2). Thus, the cores show evidence of 1982 bleaching that may

244 be concurrent with direct observations of bleaching near Jeddah, even though the cores were

245 collected $\sim 100 \mathrm{~km}$ from the pollution and freshwater sources. The 1982 event at Abu Shosha was

246 significantly less severe than 1998/2010 (95\% confidence), but I cannot exclude that minor

247 bleaching of one third or fewer Porites corals occurred (Fig. 4). Additionally, I found two stress

248 bands in 1978, and single stress bands in each of 1948 and 1931. The 1978 event is also

249 significantly less severe than 1998/2010, but the 1931 and 1948 events cannot be differentiated

250 from 1998/2010 without more samples. However, while 1978 had no heat stress, 1931 was the

251 summer with highest DHW according to HadISST (Fig. 5). It is important to recognize that both

252 the temperature and bleaching severity in 1931 are poorly constrained due to small sample sizes

253 as I collected only three cores this old and there were far fewer shipboard temperature 
254 measurements in the 1930s than recent decades (Deser et al., 2010) (Fig. 7). Nevertheless, even

255 though each is sample-size limited, the correspondence between the clear 1931 stress band in

256 core K13 and the exceptionally high heat stress during summer 1931 in HadISST leaves open the

257 possibility that this was a bleaching event.

$258 \quad$ Porites are generally considered to be relatively resistant to stress (Darling et al., 2012;

259 McClanahan et al., 2020) and have shown evidence of acclimatization to repeated marine

260 heatwaves (DeCarlo et al., 2019), meaning that they are not necessarily representative of entire

261 coral communities. It is also possible that some stress bands could arise from disturbances other

262 than high temperatures, such as disease. Finally, Porites colonies could conceivably miss a

263 bleaching event if calcification completely ceases. Nevertheless, Porites stress bands have

264 captured known bleaching events across the Indo-Pacific (Cantin \& Lough, 2014; Barkley \&

265 Cohen, 2016; DeCarlo et al., 2017, 2019, 2020; Barkley et al., 2018), and the presence of Porites

266 stress bands has correlated with community-level bleaching responses (Barkley \& Cohen, 2016;

267 Mollica et al., 2019; DeCarlo et al., 2020). Thus, that the cores from Abu Shosha generally

268 recorded the known bleaching events in 1998, 2010, and 2015 supports the accuracy of Porites

269 stress bands for representing past bleaching events in this region.

270 Heat stress in the central Red Sea is highly variable among SST datasets. Further, no

271 single SST dataset's heat stress history accurately captures both the presence and absence of

272 bleaching events. HadISST shows highest DHW in 1931 and 1998, consistent with the bleaching

273 history, but 1978, 1982, 2010, and 2015 all have lower DHW than multiple non-bleaching years.

274 ERSSTv5, in contrast, shows highest DHW in 2010 and 2015, but fails to separate all other

275 bleaching years. OI-SSTv2 only shows relatively high DHW in 1998, but not 1982, 2010, or 
276 2015. Finally, CRW has its highest DHW in 1998 and 2010, but does not separate 1982 or 2015

277 from non-bleaching years.

278 It is important to recognize both the different spatial scales of the SST datasets and the

279 potential for temporal biases due to changing measurement intensities. HadISST grid-boxes are

$2801^{\circ} \times 1^{\circ}$, which is close to half the width of the Red Sea, and the grid-box closest to Abu Shosha is

281 outside of the main shipping route where most pre-satellite measurements were made (Fig. 7).

282 Although ERSSTv2 grid-boxes are even larger, encompassing effectively the entire width of the

283 Red Sea, the closest grid-box to Abu Shosha captures the main shipping route. The satellite

284 products also differ in spatial resolution. OI-SSTv2 grid-boxes $\left(0.25^{\circ}\right)$ near Abu Shosha either

285 include a large portion of land or a combination of shelf and offshore waters, whereas CRW (5

$286 \mathrm{~km}$ ) grid-boxes are small enough to include only shelf areas (Fig. 7D). Temporally, the

287 measurement intensity of surface water temperatures from ships increased dramatically over time

288 (Fig. 7A-C), leaving greater uncertainty in earlier SST data. The satellite-based data suffer from

289 a similar problem, as new satellites have come into operation over time. OI-SSTv2 attempts to

290 minimize temporal biases by using only one type of sensor (the advanced very high resolution

291 radiometer, AVHRR) at the expense of spatial resolution, whereas CRW uses more satellites to

292 achieve greater spatial resolution at the expense of biases in some earlier years (Liu et al., 2014;

293 Banzon et al., 2016; DeCarlo \& Harrison, 2019; DeCarlo, 2020). Thus, both have certain

294 advantages, with OI-SSTv2 being more stable over time but CRW isolating shelf waters, making

295 it difficult to conclude which is most accurate at a given time without validation against

296 independent datasets.

297 Discrepancies between DHW calculated from satellite-based SST datasets have also been

298 reported for the Great Barrier Reef (GBR) of Australia (DeCarlo \& Harrison, 2019), albeit to a 
299 lesser degree than observed here in the central Red Sea. However, unlike the GBR, temperature 300 logger data from Red Sea coral reefs are, to my knowledge, unavailable prior to 2009 (Davis et

301 al., 2011; Blythe, da Silva \& Pineda, 2011; Pineda et al., 2013; DeCarlo et al., 2016), and

302 intermittent since then. Testing the accuracy of different SST datasets during only the past

303 decade is unlikely to resolve this problem because the differences are not stationary in time,

304 meaning that accuracy in recent years does not necessarily translate to accuracy in previous 305 decades (DeCarlo \& Harrison, 2019). In addition to discrepancies between satellite SST datasets

306 over broad spatial scales (kilometers), relatively large differences in temperature means and

307 variances (of up to several ${ }^{\circ} \mathrm{C}$ ) can exist over just hundreds of meters within coral reef

308 environments (Davis et al., 2011; Pineda et al., 2013; Palumbi et al., 2014; DeCarlo et al., 2017).

309 The Abu Shosha cores were collected from the reef slope on the exposed side of the reef crest

310 (Fig. 1), where diurnal cycles of heating and cooling are less than on top of the shallow reef flat

311 (Davis et al., 2011), but localized heating can still differentiate the water temperatures to which

312 these corals were exposed from the larger-scale SST represented by satellite products (Pineda et

313 al., 2013). Together, these issues present a fundamental limitation to understanding the drivers of

314 coral bleaching in the central Red Sea, especially on shallow reef flats, because there is a low

315 degree of confidence in the magnitudes of heat stress that have sparked bleaching. Corals

316 themselves can shed light on past SST variability, though, since the trace-element geochemistry

317 of their skeletons is sensitive to temperature (Corrège, 2006; Nurhati, Cobb \& Di Lorenzo,

318 2011). Previous analyses of temperature proxies in coral skeletal cores from Abu Shosha and

319 Shi'b Nazar showed some of the highest summer temperature peaks in the early 2000s (D'Olivo

320 et al., 2019; see also Murty et al., 2018), broadly consistent with the satellite data, especially

\section{OI-SSTv2.}


In addition to temperature, other factors such as light and nutrients can modulate the

323 bleaching susceptibility of corals (Brown, 1997; Dunne \& Brown, 2001; Wooldridge, 2009;

324 Cunning \& Baker, 2012; Wiedenmann et al., 2013; Vega Thurber et al., 2014; Skirving et al.,

325 2017; DeCarlo \& Harrison, 2019; DeCarlo et al., 2020). I tested if wind speed or PAR anomalies

326 correspond to bleaching events. Low-wind conditions can amplify heating on shallow reefs

327 (Davis et al., 2011; DeCarlo et al., 2017), and unusually high PAR can exacerbate heat stress

328 (Dunne \& Brown, 2001; Skirving et al., 2017). Although bleaching in this study tended to occur

329 in low-wind years, wind speed is not a unique predictor of bleaching since there are several years

330 with weaker winds than bleaching years (Fig. 8A). Additionally, low-wind conditions are likely

331 responsible for some of the positive SST anomalies, making it difficult to treat these two factors

332 as independent. Likewise, PAR anomalies do not seem to be a primary driver of bleaching here

333 since there was only a modest positive anomaly in 2010 and a negative anomaly in 2015 (Fig.

334 8B). Yet, it is possible that the exceptionally high PAR in 1998 contributed, at least in part, to the 335 severe bleaching response in that year. There are no continuous nutrient datasets available in this 336 area, but a study of summertime upwelling $\sim 300 \mathrm{~km}$ south in the Farasan Banks may offer some

337 indication of upwelled nutrient supply (DeCarlo et al., 2020). Upwelling of high-nutrient Gulf of

338 Aden Intermediate Water (GAIW) in the Farasan Banks is one of the main sources of nutrients to

339 Red Sea surface waters, and traces of GAIW (10-20\%) have been identified at the shelf edge in

340 the central Red Sea (Churchill et al., 2014). Thus, it is conceivable that corals on Abu Shosha are

341 occasionally exposed to elevated nutrients as traces of GAIW are mixed onto the shelf. Notably,

342 June-August of 1982 and 2015 were among the strongest upwelling pulses in the Farasan Banks,

343 both of which are bleaching years on Abu Shosha despite relatively low heat stress. 


\section{The past century of bleaching}

346 Below, I summarize the bleaching history of the Saudi Arabian central Red Sea as

347 inferred from coral cores and direct observations, in addition to the heat stress history during

348 these bleaching years.

1931: SST may have been anomalously high, especially in August, but HadISST and

ERSSTv5 disagree on the magnitude of the heat stress $\left(6.0\right.$ and $2.8^{\circ} \mathrm{C}$-weeks, respectively). A

351 single stress band was found corresponding to 1931, but only two cores from Abu Shosha extend

352 this far back. Thus, 1931 is a potential bleaching year, but limitations in both the SST and stress

353 band data prevent definitive conclusions.

1948: A single stress band was found in an outer-shelf core, but no other stress bands

355

356

357

358

359

360

361

362

363

364

365

366

were found either in two other cores from mid- or outer-shelf reefs or in four cores from Abu

Shosha. Neither HadISST nor ERSSTv5 show any heat stress at this time. Thus, 1948 is unlikely

to have been a severe bleaching event, but rather was more likely to have been either a minor

bleaching event or a non-temperature disturbance to this specific coral.

1978: Two stress bands were found in this year, one from an outer-shelf reef and another

at Abu Shosha. The sample size of cores was sufficient to exclude that an event affecting 8 out of

11 Porites occurred from 1934 through 1978 at Abu Shosha, and from 1949 through 1978

outside of Abu Shosha. However, an event affecting 1 out of 3 Porites in 1978 could not be

excluded, leaving open the possibility that a minor bleaching event affected reefs across the

shelf. The 1978 stress bands in cores K6 and K14 are both clear, but there are no stress bands in the other 13 cores of this age ( 9 from Abu Shosha and 4 from other reefs). Both HadISST and ERSSTv5 show no heat stress as this time. Although the co-occurrence of two stress bands in

Peer] reviewing PDF | (2020:07:50935:1:1:NEW 4 Sep 2020) 
367 this year lends support to this being a real bleaching event, it probably affected a relatively small

368 proportion of corals, and the environmental driver of any bleaching in 1978 is unclear.

369 1982: This year marks the first occurrence of stress bands in multiple cores from one reef,

370 similar to the results of a similar study on the northern GBR and in the Coral Sea (DeCarlo et al.,

371 2019). Likewise, 1982/1983 is the first known large-scale bleaching event that stretched across

372 the Pacific Ocean (Glynn, 1983; Oliver, 1985). Some bleaching was observed near Jeddah

373 around this time, but key details such as specific times, places, and bleaching extent are lacking

374 (Antonius, 1988). SST datasets, including HadISST, ERSSTv5, and the satellite-based OI-SSTv2

375 all show no heat stress during this year. However, satellite-based SST also showed very little

376 heat stress on the GBR in 1982 (DeCarlo \& Harrison, 2019) even though the majority of corals

377 bleached, and more than half died, on most nearshore reefs that were monitored at the time

378 (Oliver, 1985). Furthermore, coral cores in the southern Red Sea show 1982 stress bands, albeit

379 in $<15 \%$ of corals, despite similarly low heat stress, likely a result of nutrient-injection from the

380 strong upwelling that preceded bleaching there (DeCarlo et al., 2020). Therefore, I suggest that

3811982 was probably a minor bleaching event on Abu Shosha even though heat stress was

382 apparently either low or absent. This could be a result of either inaccuracies in the SST datasets

$383 \mathrm{and} /$ or the exacerbation of minor heat stress by upwelled nutrients early in the summer.

3841998 : This is the only year that all four SST datasets agree that there was relatively high

385 heat stress. Additionally, 1998 is the first time that mass coral bleaching in the central Red Sea

386 was observed and recorded by scientists (Devantier \& Pilcher, 2000). Although it is unclear if

387 Abu Shosha itself was surveyed at this time, up to $65 \%$ of corals bleached on nearshore reefs

388 around Rabigh, only $50 \mathrm{~km}$ to the north (Devantier \& Pilcher, 2000). Consistent with the visual

389 observations, coral cores from Abu Shosha reveal evidence of severe bleaching, with clear stress 
390 bands in 8 out of 11 cores. I can conclude with $95 \%$ confidence that no prior event reached this

391 severity since 1934. Skeletal geochemistry of Abu Shosha Porites was also perturbed during this

392 event, indicative of disruptions to the normal calcification process (D'Olivo et al., 2019). The

393 complete absence of stress bands in cores outside of Abu Shosha suggests this event may have

394 been restricted to nearshore environments.

2010: Similar to 1998, coral bleaching was observed directly on nearshore reefs in the

central Red Sea in 2010, and this is corroborated by stress bands in 8 out of 11 cores at Abu

Shosha. However, unlike 1998, not all SST datasets agree that there was substantial heat stress,

with unprecedented DHW in ERSSTv5 and CRW, but relatively low DHW in HadISST and OI-

SSTv2. Previous investigations of this bleaching event suggest that it arose from an eddy that constrained warm water near the coast (Pineda et al., 2013), which is only detectable in CRW.

Thus, this event likely rivalled 1998 in severity on Abu Shosha, but probably reached a lesser

402 extent of the Red Sea than previous bleaching events in 1982 and 1998 (Furby, Bouwmeester \&

403 Berumen, 2013). Only one core from outside Abu Shosha contained a 2010 stress band,

404 indicating that - like 1998 - this event mostly affected nearshore reefs, but there may have been

405 minor effects on other reefs across the shelf.

406

2015: Coral bleaching was again directly observed in 2015 , including approximately one

407 third of Porites colonies at Abu Shosha and Qita Al-Kirsh (Monroe et al., 2018), where cores

$408 \mathrm{~K} 11$ and K12 were collected. However, the coral cores barely registered this event, with only 1

409 out of 11 Abu Shosha cores containing a faint stress band. Although this result is not

410 significantly different from expected if only $1 / 3$ of Porites bleached, it represents a marked

411 difference in the Porites response compared to 1998 and 2010. This suggests that either

412 bleaching was more severe on Abu Shosha in 1998 and 2010 than 2015, or that these colonies 
413 acclimatized following their previous exposure to heat stress, similar to results from the GBR

414 (DeCarlo et al., 2019). No cores outside of Abu Shosha contained 2015 stress bands, although

415 the outer-shelf reefs had $<10 \%$ bleaching at this time in benthic surveys, including Shi'b Nazar

416 (cores K4 and K5) (Monroe et al., 2018). As discussed previously (Monroe et al., 2018), there

417 was little heat stress in 2015, with only the low-resolution ERSSTv5 showing substantial DHW.

418 Like 1982, it is possible that minor heat stress was exacerbated by upwelled nutrients since 2015

419 was one of the strongest GAIW upwelling years of the satellite era (DeCarlo et al., 2020).

420

421 Conclusion

422 Regardless of uncertainties in the precise DHW during each individual year, it is clear

423 that heat stress events have become more common and of higher magnitude since 1998.

424 Likewise, the three bleaching events during this time (1998, 2010, and 2015) left signatures in

425 the nearshore coral skeletal cores that, when viewed as a whole, are unprecedented in terms of

426 frequency and severity since at least the mid-1930s. One potential glimmer of hope is that the

427 results here suggest these corals may have acclimatized after 1998 and 2010, such that they were

428 less affected by bleaching in 2015 (i.e., they may have bleached but not formed stress bands),

429 consistent with signs of acclimatization in other regions (Vargas-Ángel et al., 2001; Guest et al.,

430 2012; Pratchett et al., 2013; Putnam \& Gates, 2015; Gintert et al., 2018; Coles et al., 2018;

431 DeCarlo et al., 2019). Additionally, mid- and outer-shelf reefs have been less sensitive to heat

432 stress than those nearshore, with evidence of only minor bleaching events in the skeletal cores

433 and no apparent increase in frequency or severity in recent decades. A similar pattern of highly

434 susceptible nearshore corals and more resilient offshore corals has been reported in the

435 Mesoamerican reef system (Baumann et al., 2019). As sea surface temperatures increase in the 
436 coming decades, the central Red Sea will be subjected to more frequent and intense heat stress

437 events (Cantin et al., 2010; van Hooidonk, Maynard \& Planes, 2013; Hoegh-Guldberg et al.,

438 2014). Corals living on nearshore reefs of this region are therefore likely to experience more

439 severe bleaching events with diminishing return times, unless they can acclimatize or adapt fast

440 enough. On the other hand, corals on outer-shelf reefs of the Saudi Arabian central Red Sea-

441 like their counterparts in the northern Red Sea-have so far avoided severe bleaching, but we do

442 not yet know whether this resistance will be maintained as the ocean continues to warm.

443

444 Data accessibility:

445 Raw data and code are available at: https://codeocean.com/capsule/9706930

446

447 Acknowledgements:

448 I thank Vincent Saderne, Anna Knochel, Alex Kattan, Walter Rich, Alyssa Bell, Claire Shellem, 449 Aislinn Dunne, Ashlie McIvor, Irene Salines-Akhmadeeva, and Michelle Havlik for assistance in 450 the field.

451

452 Conflict of interest:

453 The author declares that there are no conflicts of interest.

454

455 References:

456 Antonius A. 1988. Distribution and dynamics of coral diseases in the Eastern Red Sea. In:

457 Proceedings of the 6th International Coral Reef Symposium, Australia.

458 Baker AC, Glynn PW, Riegl B. 2008. Climate change and coral reef bleaching: An ecological 
459

460

461

462

463

464

465

466

467

468

469

470

471

472

473

474

475

476

477

478

479

480

481

assessment of long-term impacts, recovery trends and future outlook. Estuarine, Coastal and Shelf Science 80:435-471.

Banzon V, Smith TM, Chin TM, Liu C, Hankins W. 2016. A long-term record of blended satellite and in situ sea-surface temperature for climate monitoring, modeling and environmental studies. Earth System Science Data 8:165-176. DOI: 10.5194/essd-8-1652016.

Barkley HC, Cohen AL. 2016. Skeletal records of community-level bleaching in Porites corals from Palau. Coral Reefs 35:1407-1417. DOI: 10.1007/s00338-016-1483-3.

Barkley H, Cohen A, Mollica N, Brainard R, Rivera H, DeCarlo T, Lohmann G, Drenkard E, Alpert A, Young C, Vargas-Angel B, Lino K, Oliver T, Pietro K, Luu V. 2018. Repeat bleaching of a central Pacific coral reef over the past six decades (1960-2016). Communications Biology 1:177.

Baumann JH, Ries JB, Rippe JP, Courtney TA, Aichelman HE, Westfield I, Castillo KD. 2019. Nearshore coral growth declining on the Mesoamerican Barrier Reef System. Global Change Biology 25:3932-3945. DOI: 10.1111/gcb.14784.

Berumen ML, Voolstra CR, Daffonchio D, Agusti S, Aranda M, Irigoien X, Jones BH, Morán XAG, Duarte CM. 2019. The Red Sea: Environmental Gradients Shape a Natural Laboratory in a Nascent Ocean. In: Berumen M, Voolstra C eds. Coral Reefs of the Red Sea. 1-10. DOI: 10.1007/978-3-030-05802-9_1.

Blythe JN, da Silva JCB, Pineda J. 2011. Nearshore, seasonally persistent fronts in sea surface temperature on Red Sea tropical reefs. ICES Journal of Marine Science 68:1827-1832. DOI: $10.1093 /$ icesjms/fsr109.

Brown BE. 1997. Coral bleaching: causes and consequences. Coral Reefs 16:129-138. 
482 C3S CCCS. 2017. ERA5: Fifth generation of ECMWF atmospheric reanalyses of the global 483 climate.

484 Cantin NE, Cohen AL, Karnauskas KB, Tarrant AM, McCorkle DC. 2010. Ocean warming 485 slows coral growth in the central Red Sea. Science 329:322.

486 Cantin NE, Lough JM. 2014. Surviving Coral Bleaching Events: Porites Growth Anomalies on 487 the Great Barrier Reef. PLoS One 9:e88720.

488 Carilli JE, Norris RD, Black BA, Walsh SM, McField M. 2009. Local Stressors Reduce Coral $489 \quad$ Resilience to Bleaching. PLoS One 4:e6324.

490 Cavole LM, DeCarlo TM. 2020. Early observations of heat-induced coral bleaching in the 491 Galápagos Islands. Reef Encounter 35:68-72.

492 Churchill JH, Bower AS, McCorkle DC, Abualnaja Y. 2014. The transport of nutrient-rich 493 Indian Ocean water through the Red Sea and into coastal reef systems. Journal of Marine $494 \quad$ Research 72:165-181. DOI: 10.1357/002224014814901994.

495 Churchill JH, Davis K, Wurgaft E, Shaked Y. 2019. Environmental setting for reef building in 496 the Red Sea. In: Berumen ML, Voolstra CR eds. Coral Reefs of the Red Sea. 11-32. DOI: $497 \quad 10.1007 / 978-3-030-05802-9 \_2$.

498 Coffroth MA, Lasker HR, Oliver JK. 1990. Coral Mortality Outside of the Eastern Pacific 499 During 1982-1983: Relationship to El Niño. Elsevier Oceanography Series 52:141-182. 500 DOI: $10.1016 / \mathrm{S} 0422-9894(08) 70035-7$.

501 Coles SL, Bahr KD, Rodgers KS, May SL, McGowan AE, Tsang A, Bumgarner J, Han JH. 502 2018. Evidence of acclimatization or adaptation in Hawaiian corals to higher ocean 503 temperatures. PeerJ 6:e5347. DOI: 10.7717/peerj.5347.

504 Corrège T. 2006. Sea surface temperature and salinity reconstruction from coral geochemical 
505

506

507 Cunning R, Baker AC. 2012. Excess algal symbionts increase the susceptibility of reef corals to

509 D’Olivo JP, Georgiou L, Falter J, DeCarlo TM, Irigoien X, Voolstra CR, Roder C, Trotter J,

510 McCulloch MT. 2019. Long-term impacts of the 1997-1998 bleaching event on the growth

511 and resilience of massive Porites corals from the central Red Sea. Geochemistry,

512 Geophysics, Geosystems 20:2019GC008312. DOI: 10.1029/2019GC008312.

513 Darling ES, Alvarez-Filip L, Oliver TA, McClanahan TR, Côté IM. 2012. Evaluating life-history

$514 \quad$ strategies of reef corals from species traits. Ecology Letters 15:1378-1386. DOI:

$515 \quad$ 10.1111/j.1461-0248.2012.01861.x.

516 Davis KA, Lentz SJ, Pineda J, Farrar JT, Starczak VR, Churchill JH. 2011. Observations of the

517 thermal environment on Red Sea platform reefs: a heat budget analysis. Coral Reefs 30:25$518 \quad 36$.

519 DeCarlo TM. 2020. Treating coral bleaching as weather: a framework to validate and optimize 520 prediction skill. PeerJ 8:e9449. DOI: 10.7717/peerj.9449.

521 DeCarlo TM, Cohen AL. 2017. Dissepiments, density bands and signatures of thermal stress in

522 Porites skeletons. Coral Reefs 36:749-761. DOI: 10.1007/s00338-017-1566-9.

523 DeCarlo TM, Cohen AL, Wong GTF, Davis KA, Lohmann P, Soong K. 2017. Mass coral 524 mortality under local amplification of $2{ }^{\circ} \mathrm{C}$ ocean warming. Scientific Reports 7:44586.

$525 \quad$ DOI: $10.1038 / \operatorname{srep} 44586$.

526 DeCarlo TM, Gaetani GA, Cohen AL, Foster GL, Alpert AE, Stewart J. 2016. Coral Sr-U

527 Thermometry. Paleoceanography 31:626-638. DOI: 10.1002/2015PA002908. 
528 DeCarlo TM, Gajdzik L, Ellis J, Coker DJ, Roberts MB, Hammerman NM, Pandolfi JM,

529 Monroe AA, Berumen ML. 2020. Nutrient-supplying ocean currents modulate coral

$530 \quad$ bleaching susceptibility. Science Advances 6:eabc5493.

531 DeCarlo TM, Harrison HB. 2019. An enigmatic decoupling between heat stress and coral

532 bleaching on the Great Barrier Reef. PeerJ 7:e7473. DOI: 10.7717/peerj.7473.

533 DeCarlo TM, Harrison HB, Gajdzik L, Alaguarda D, Rodolfo-Metalpa R, D’Olivo J, Liu G,

534 Patalwala D, McCulloch MT. 2019. Acclimatization of massive reef-building corals to

535 consecutive heatwaves. Proceedings of the Royal Society B: Biological Sciences

$536 \quad 286: 20190235$. DOI: $10.1098 / \mathrm{rspb} .2019 .0235$.

537 Deser C, Alexander MA, Xie S-P, Phillips AS. 2010. Sea Surface Temperature Variability:

538 Patterns and Mechanisms. Annual Review of Marine Science 2:115-143. DOI:

539 10.1146/annurev-marine-120408-151453.

540 Devantier L, Pilcher N. 2000. The status of coral reefs in Saudi Arabia - 2000.

541 Devantier L, Turak E, Al-Shaikh K, De'ath G. 2000. Coral communities of the central-northern

542 Saudi Arabian Red Sea. Fauna of Arabia 18:23-66.

543 Dunne R, Brown B. 2001. The influence of solar radiation on bleaching of shallow water reef

544 corals in the Andaman Sea, 1993-1998. Coral Reefs 20:201-210. DOI:

$545 \quad 10.1007 / \mathrm{s} 003380100160$.

546 Fine M, Gildor H, Genin A. 2013. A coral reef refuge in the Red Sea. Global Change Biology

547 19:3640-3647. DOI: 10.1111/gcb.12356.

548 Frouin R, Franz B, Werdell P. 2002. The SeaWiFS PAR product. In: Hooker S, Firestone E eds.

549 Algorithm Updates for the Fourth SeaWiFS Data Reprocessing. NASA Technical

$550 \quad$ Memorandum, 46-50. 
551 Furby KA, Bouwmeester J, Berumen ML. 2013. Susceptibility of central Red Sea corals during a 552 major bleaching event. Coral Reefs 32:505-513. DOI: 10.1007/s00338-012-0998-5.

553 Gintert BE, Manzello DP, Enochs IC, Kolodziej G, Carlton R, Gleason ACR, Gracias N. 2018.

$554 \quad$ Marked annual coral bleaching resilience of an inshore patch reef in the Florida Keys: A 555 nugget of hope, aberrance, or last man standing? Coral Reefs 37:533-547. DOI:

$556 \quad 10.1007 / \mathrm{s} 00338-018-1678-\mathrm{x}$.

557 Glynn PW. 1983. Extensive 'bleaching' and death of reef corals on the Pacific coast of Panama. $558 \quad$ Environmental Conservation 10:149-154.

559 Glynn PW. 1993. Coral reef bleaching: ecological perspectives. Coral Reefs 12:1-17. DOI: $560 \quad 10.1007 / \mathrm{BF} 00303779$.

561 Goreau TF. 1964. Mass Expulsion of Zooxanthellae from Jamaican Reef Communities after $562 \quad$ Hurricane Flora. Science 145:383-6. DOI: 10.1126/science.145.3630.383.

563 Grottoli AG, Rodrigues LJ, Juarez C. 2004. Lipids and stable carbon isotopes in two species of 564 Hawaiian corals, Porites compressa and Montipora verrucosa, following a bleaching event. $565 \quad$ Marine Biology 145:621-631.

566 Guest JR, Baird AH, Maynard JA, Muttaqin E, Edwards AJ, Campbell SJ, Yewdall K, Affendi 567 YA, Chou LM. 2012. Contrasting Patterns of Coral Bleaching Susceptibility in 2010 568 Suggest an Adaptive Response to Thermal Stress. PLoS ONE 7:e33353. DOI: $569 \quad 10.1371 /$ journal.pone.0033353.

570 Hendy EJ, Lough JM, Gagan MK. 2003. Historical mortality in massive Porites from the central $571 \quad$ Great Barrier Reef, Australia: evidence for past environmental stress? Coral Reefs 22:207572 215. DOI: $10.1007 / \mathrm{s} 00338-003-0304-7$.

573 Hoegh-Guldberg O, Cai R, Poloczanska E, Brewer P, Sundby S, Helmi K, Fabry V, Jung S. 
574

575

576

577

578

579

580

581

582

583

584

585

586

587

588

589

590

591

592

593

594

595

596

2014. The Ocean. In: Barros V, Field C, Dokken D, Mastrandrea M, Mach K, Bilir T, Chatterjee M, Ebi K, Estrada Y, Genova R, Girma B, Kissel E, Levy A, MacCracken S, Mastrandrea P, White L eds. Climate Change 2014: Impacts, Adaptation, and Vulnerability. Contribution of Working Group 2 to the Fifth Assessment Report of the Intergovernmental Panel on Climate Change. Cambridge, United Kingdom and New York, NY, USA: Cambridge University Press,.

Hoegh-Guldberg O, Fine M. 2004. Low temperatures cause coral bleaching. Coral Reefs 23:444. DOI: $10.1007 / \mathrm{s} 00338-004-0401-2$.

van Hooidonk R, Maynard JA, Planes S. 2013. Temporary refugia for coral reefs in a warming world. Nature Climate Change 3:508-511. DOI: 10.1038/nclimate1829.

Huang B, Thorne PW, Banzon VF, Boyer T, Chepurin G, Lawrimore JH, Menne MJ, Smith TM, Vose RS, Zhang H-M. 2017. Extended Reconstructed Sea Surface Temperature, Version 5 (ERSSTv5): Upgrades, Validations, and Intercomparisons. Journal of Climate 30:8179_ 8205. DOI: $10.1175 / J C L I-D-16-0836.1$.

Hudson JH, Shinn EA, Halley RB, Lidz B. 1976. Sclerochronology: A tool for interpreting past environments. Geology 4:361-364. DOI: 10.1130/0091-7613(1976)4.

Hughes TP, Anderson KD, Connolly SR, Heron SF, Kerry JT, Lough JM, Baird AH, Baum JK, Berumen ML, Bridge TC, Claar DC, Eakin CM, Gilmour JP, Graham NAJ, Harrison H, Hobbs J-PA, Hoey AS, Hoogenboom M, Lowe RJ, McCulloch MT, Pandolfi JM, Pratchett M, Schoepf V, Torda G, Wilson SK. 2018. Spatial and temporal patterns of mass bleaching of corals in the Anthropocene. Science 359:80-83. DOI: 10.1126/science.aan8048.

Hughes TP, Kerry JT, Álvarez-Noriega M, Álvarez-Romero JG, Anderson KD, Baird AH, Babcock RC, Beger M, Bellwood DR, Berkelmans R, Bridge TC, Butler IR, Byrne M, 
597 Cantin NE, Comeau S, Connolly SR, Cumming GS, Dalton SJ, Diaz-Pulido G, Eakin CM, 598 Figueira WF, Gilmour JP, Harrison HB, Heron SF, Hoey AS, Hobbs J-PA, Hoogenboom 599 MO, Kennedy E V., Kuo C, Lough JM, Lowe RJ, Liu G, McCulloch MT, Malcolm HA, 600 McWilliam MJ, Pandolfi JM, Pears RJ, Pratchett MS, Schoepf V, Simpson T, Skirving WJ, 601 Sommer B, Torda G, Wachenfeld DR, Willis BL, Wilson SK. 2017. Global warming and 602 recurrent mass bleaching of corals. Nature 543:373-377. DOI: 10.1038/nature21707.

603 Karnauskas KB, Jones BH. 2018. The Interannual Variability of Sea Surface Temperature in the 604 Red Sea From 35 Years of Satellite and In Situ Observations. Journal of Geophysical 605 Research: Oceans 123:5824-5841. DOI: 10.1029/2017JC013320.

606 Kleinhaus K, Al-Sawalmih A, Barshis DJ, Genin A, Grace LN, Hoegh-Guldberg O, Loya Y, 607 Meibom A, Osman EO, Ruch J-D, Shaked Y, Voolstra CR, Zvuloni A, Fine M. 2020. 608 Science, Diplomacy, and the Red Sea's Unique Coral Reef: It's Time for Action. Frontiers 609 in Marine Science 7:90. DOI: 10.3389/fmars.2020.00090.

610 Krokos G, Papadopoulos VP, Sofianos SS, Ombao H, Dybczak P, Hoteit I. 2019. Natural 611 Climate Oscillations may Counteract Red Sea Warming Over the Coming Decades. 612 Geophysical Research Letters 46:3454-3461. DOI: 10.1029/2018GL081397.

613 Krueger T, Horwitz N, Bodin J, Giovani M-E, Escrig S, Meibom A, Fine M. 2017. Common 614 reef-building coral in the Northern Red Sea resistant to elevated temperature and 615 acidification. Royal Society Open Science 4:170038. DOI: 10.1098/rsos.170038.

616 Lesser MP. 1997. Oxidative stress causes coral bleaching during exposure to elevated 617 temperatures. Coral Reefs 16:187-192. DOI: 10.1007/s003380050073.

618 Liu G, Heron S, Eakin C, Muller-Karger F, Vega-Rodriguez M, Guild L, De La Cour J, Geiger 619 E, Skirving W, Burgess T, Strong A, Harris A, Maturi E, Ignatov A, Sapper J, Li J, Lynds 
620

621

622

623

624

625

626

627

628

629

630

631

632

633

634

635

636

637

638

639

640

641

642

S. 2014. Reef-scale thermal stress monitoring of coral ecosystems: new 5-km global products from NOAA Coral Reef Watch. Remote Sensing 6:11579-11606. DOI: $10.3390 /$ rs61111579.

Liu G, Strong AE, Skirving W. 2003. Remote sensing of sea surface temperatures during 2002 Barrier Reef coral bleaching. Eos, Transactions American Geophysical Union 84:137-141. DOI: $10.1029 / 2003 E O 150001$.

Lough JM, Anderson KD, Hughes TP. 2018. Increasing thermal stress for tropical coral reefs: 1871-2017. Scientific Reports 8:6079. DOI: 10.1038/s41598-018-24530-9.

McClanahan T, Darling E, Maina J, Muthiga N, D’agata S, Leblond J, Arthur R, Jupiter S, Wilson S, Mangubhai S, Ussi A, Guillaume M, Humphries A, Patankar V, Shedrawi G, Pagu J, Grimsditch G. 2020. Highly variable taxa-specific coral bleaching responses to thermal stresses. Marine Ecology Progress Series 648:135-151. DOI: 10.3354/meps13402.

Mendes JM, Woodley JD. 2002. Effect of the 1995-1996 bleaching event on polyp tissue depth, growth, reproduction and skeletal band formation in Montastraea annularis. Mar. Ecol. Prog. Ser. 235:93-102.

Mollica NR, Cohen AL, Alpert AE, Barkley HC, Brainard RE, Carilli JE, DeCarlo TM, Drenkard EJ, Lohmann P, Mangubhai S, Pietro KR, Rivera HE, Rotjan RD, Scott-Buechler C, Solow AR, Young CW. 2019. Skeletal records of bleaching reveal different thermal thresholds of Pacific coral reef assemblages. Coral Reefs 38:743-757. DOI: 10.1007/s00338-019-01803-X.

Monroe AA, Ziegler M, Roik A, Röthig T, Hardenstine RS, Emms MA, Jensen T, Voolstra CR, Berumen ML. 2018. In situ observations of coral bleaching in the central Saudi Arabian Red Sea during the 2015/2016 global coral bleaching event. PLOS ONE 13:e0195814. DOI: 
10.1371/journal.pone.0195814.

644 Montaggioni LF, Behairy AKA, El-Sayed MK, Yusuf N. 1986. The modern reef complex,

645 Jeddah area, Red Sea: a facies model for carbonate sedimentation on embryonic passive

646 margins. Coral Reefs 5:127-150. DOI: 10.1007/BF00298180.

647 Murty SA, Bernstein WN, Ossolinski JE, Davis RS, Goodkin NF, Hughen KA. 2018. Spatial and

648 Temporal Robustness of Sr/Ca-SST Calibrations in Red Sea Corals: Evidence for Influence

649 of Mean Annual Temperature on Calibration Slopes. Paleoceanography and

650 Paleoclimatology 33:443-456. DOI: 10.1029/2017PA003276.

651 Muscatine L, Grossman D, Doino J. 1991. Release of symbiotic algae by tropical sea anemones

652 and corals after cold shock. Marine Ecology Progress Series 77:233-243. DOI:

$653 \quad 10.2307 / 24826575$.

654 Nurhati IS, Cobb KM, Di Lorenzo E. 2011. Decadal-scale SST and salinity variations in the

655 central tropical Pacific: Signatures of natural and anthropogenic climate change. Journal of

656 Climate 24:3294-3308. DOI: http://dx.doi.org/10.1175/2011JCLI3852.1.

657 Oliver J. 1985. Recurrent seasonal bleaching and mortality of corals on the Great Barrier Reef.

658 In: Proceedings of the Fifth International Coral Reef Congress, Tahiti. Tahiti,.

659 Osman EO, Smith DJ, Ziegler M, Kürten B, Conrad C, El-Haddad KM, Voolstra CR, Suggett

660 DJ. 2018. Thermal refugia against coral bleaching throughout the northern Red Sea. Global

661 Change Biology 24:e474-e484. DOI: 10.1111/gcb.13895.

662 Palumbi SR, Barshis DJ, Traylor-Knowles N, Bay RA. 2014. Mechanisms of Reef Coral

663 Resistance to Future Climate Change. Science 344:895-898.

664 Paz-García DA, Balart EF, García-De-Léon FJ. 2012. Cold water bleaching of Pocillopora in the

665 Gulf of California. In: Proceedings of the 12th International Coral Reef Symposium, 
667 Pineda J, Starczak V, Tarrant A, Blythe J, Davis K, Farrar T, Berumen M, da Silva JCB. 2013.

668 Two spatial scales in a bleaching event: Corals from the mildest and the most extreme 669 thermal environments escape mortality. Limnology and Oceanography 58:1531-1545. DOI: $670 \quad 10.4319 / 10.2013 .58 .5 .1531$.

671 Pratchett MS, McCowan D, Maynard JA, Heron SF. 2013. Changes in Bleaching Susceptibility 672 among Corals Subject to Ocean Warming and Recurrent Bleaching in Moorea, French 673 Polynesia. PLoS ONE 8:e70443. DOI: 10.1371/journal.pone.0070443.

674 Putnam HM, Gates RD. 2015. Preconditioning in the reef-building coral Pocillopora damicornis 675 and the potential for trans-generational acclimatization in coral larvae under future climate 676 change conditions. Journal of Experimental Biology 218:2365-2372. DOI:

677 10.1242/jeb.123018.

678 Raitsos DE, Hoteit I, Prihartato PK, Chronis T, Triantafyllou G, Abualnaja Y. 2011. Abrupt 679 warming of the Red Sea. Geophysical Research Letters 38. DOI: 10.1029/2011GL047984.

680 Rayner NA, Parker DE, Horton EB, Folland CK, Alexander L V., Rowell DP, Kent EC, Kaplan 681 A. 2003. Global analyses of sea surface temperature, sea ice, and night marine air 682 temperature since the late nineteenth century. Journal of Geophysical Research 108:4407. 683 DOI: $10.1029 / 2002 J D 002670$.

684 Reynolds RW, Smith TM, Liu C, Chelton DB, Casey KS, Schlax MG. 2007. Daily high685 resolution-blended analyses for sea surface temperature. Journal of Climate 20:5473-5496. 686 DOI: $10.1175 / 2007$ JCLI1824.1.

687 Rowlands G, Purkis S, Riegl B, Metsamaa L, Bruckner A, Renaud P. 2012. Satellite imaging 688 coral reef resilience at regional scale. A case-study from Saudi Arabia. Marine Pollution 
690 Saxby T, Dennison W, Hoegh-Guldberg O. 2003. Photosynthetic responses of the coral

691 Montipora digitata to cold temperature stress. Marine Ecology Progress Series 248:85-97.

692 DOI: $10.3354 /$ meps248085.

693 Skirving W, Enríquez S, Hedley J, Dove S, Eakin C, Mason R, De La Cour J, Liu G, Hoegh694 Guldberg O, Strong A, Mumby P, Iglesias-Prieto R, Skirving W, Enríquez S, Hedley JD, 695 Dove S, Eakin CM, Mason RAB, De La Cour JL, Liu G, Hoegh-Guldberg O, Strong AE, 696 Mumby PJ, Iglesias-Prieto R. 2017. Remote Sensing of Coral Bleaching Using Temperature and Light: Progress towards an Operational Algorithm. Remote Sensing 10:18. DOI:

698 $10.3390 /$ rs 10010018 .

699

700

701

702

703

704

705

706

707

708

709

710

711

Sully S, Burkepile DE, Donovan MK, Hodgson G, van Woesik R. 2019. A global analysis of coral bleaching over the past two decades. Nature Communications 10:1264. DOI: 10.1038/s41467-019-09238-2.

Terraneo TI, Benzoni F, Baird AH, Arrigoni R, Berumen ML. 2019. Morphology and molecules reveal two new species of Porites (Scleractinia, Poritidae) from the Red Sea and the Gulf of Aden. Systematics and Biodiversity 17:491-508. DOI: 10.1080/14772000.2019.1643806.

Vargas-Ángel B, Zapata FA, Hernández H, Jiménez JM. 2001. Coral and coral reef responses to the 1997-98 El Niño event on the Pacific coast of Colombia. Bulletin of Marine Science 69:111-132.

Vega Thurber RL, Burkepile DE, Fuchs C, Shantz AA, McMinds R, Zaneveld JR. 2014. Chronic nutrient enrichment increases prevalence and severity of coral disease and bleaching. Global Change Biology 20:544-554. DOI: 10.1111/gcb.12450.

Wiedenmann J, D’Angelo C, Smith EG, Hunt AN, Legiret F-E, Postle AD, Achterberg EP. 2013. 
712 Nutrient enrichment can increase the susceptibility of reef corals to bleaching. Nature

713 Climate Change 3:160-164. DOI: https://doi.org/10.1038/nclimate1661.

714 Wooldridge SA. 2009. Water quality and coral bleaching thresholds: Formalising the linkage for 715 the inshore reefs of the Great Barrier Reef, Australia. Marine Pollution Bulletin 58:745-

716 751. DOI: 10.1016/J.MARPOLBUL.2008.12.013.

717 Yonge CM, Nicholls AG. 1931. Studies on the physiology of corals: IV. The structure,

718 distribution, and physiology of the zooxanthellae. Scientific Reports / Great Barrier Reef

719 Expedition 1928-29 1:135-176.

720 


\section{Figure 1}

Study region in the Saudi Arabian central Red Sea.

(A) Red Sea coastlines (black) from the GSHHG database (Wessel \& Smith, 1996) , and 100-meter isobath (Amante \& Eakins, 2009) to delineate the shelf edge (gray). (B-C) Satellite imagery (ESRI/Maxar) of the Thuwal region (B) and Abu Shosha (C), with coral drilling locations shown as pink dots and the shelf edge (100-m isobath) indicated by the dashed white line.

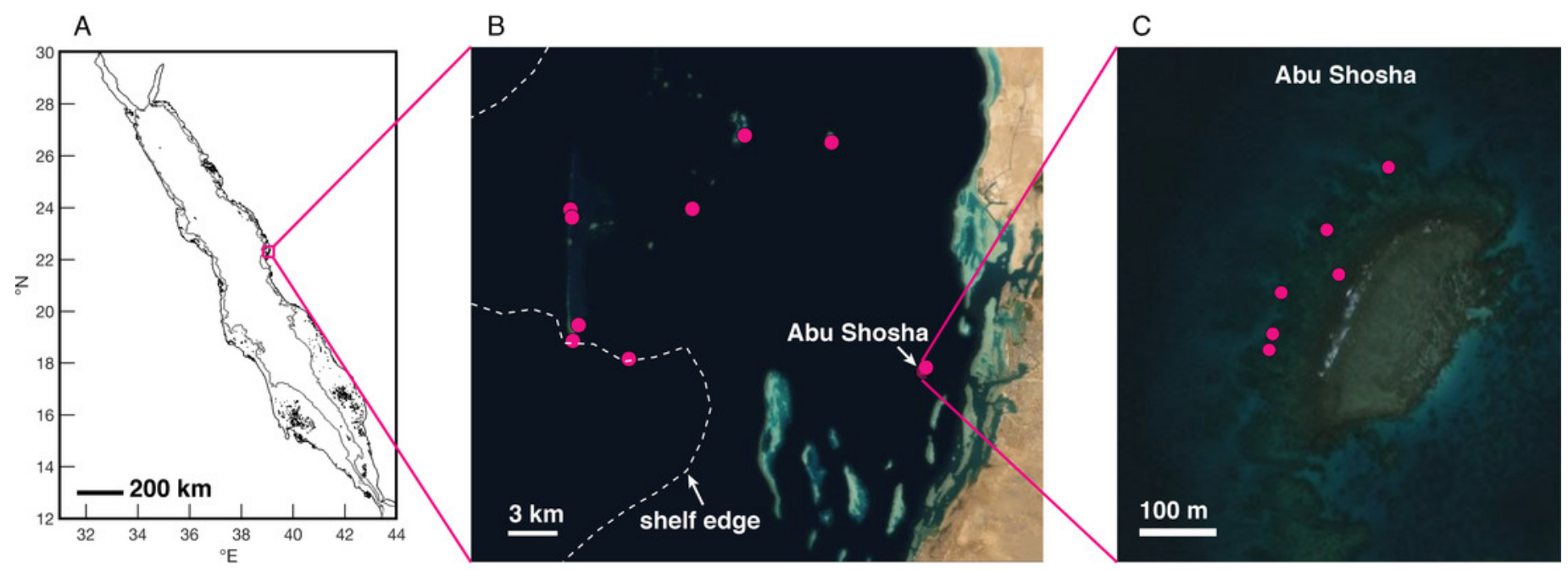




\section{Figure 2}

CT scans of coral skeletal cores from Abu Shosha.

Light (dark) shading indicates relatively high (low) density. The brightness and contrast of each core was adjusted separately to best visualize banding patterns, meaning that shading is comparable within, but not between, cores. Yellow lines connect across cores the first year (2019) and previous decades beginning with 2000. The oldest band of each core is also indicated. Dashed white lines connect stress bands across cores. Core ID numbers are shown at the top in white text. Inset boxes show higher magnification images of stress bands, grouped by year. In some cases, a different digital slice from the main core image was selected to better view the stress bands. Arrows and white lines between cores in inset images indicate the stress bands. The 10-cm scale bar in the main figure applies to all cores, whereas each image in the stress-band inset boxes has its own 1-cm scale bar. 


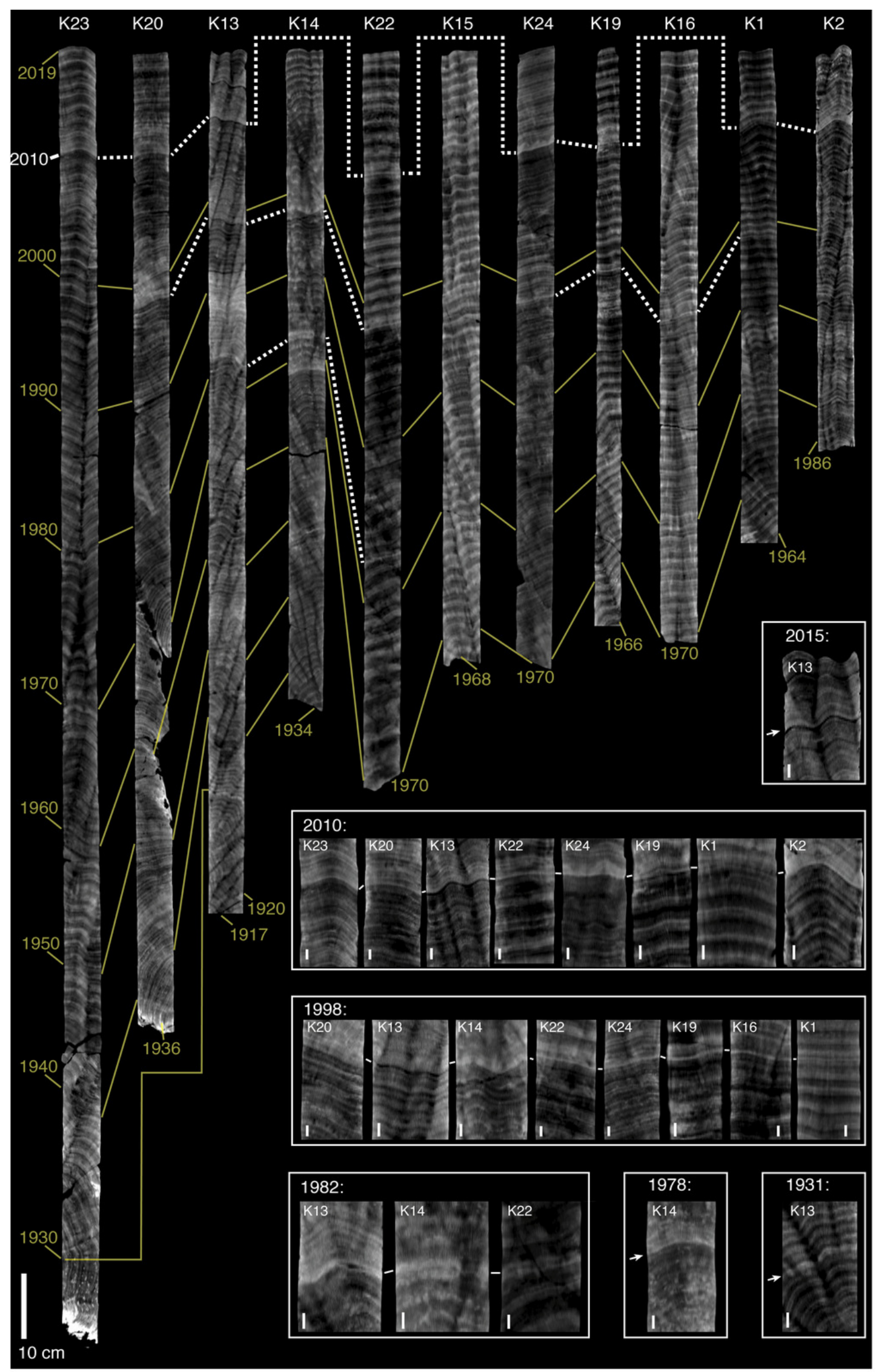




\section{Figure 3}

CT scans of coral skeletal cores collected outside of Abu Shosha.

Refer to figure 2 legend for a full description of the figure.

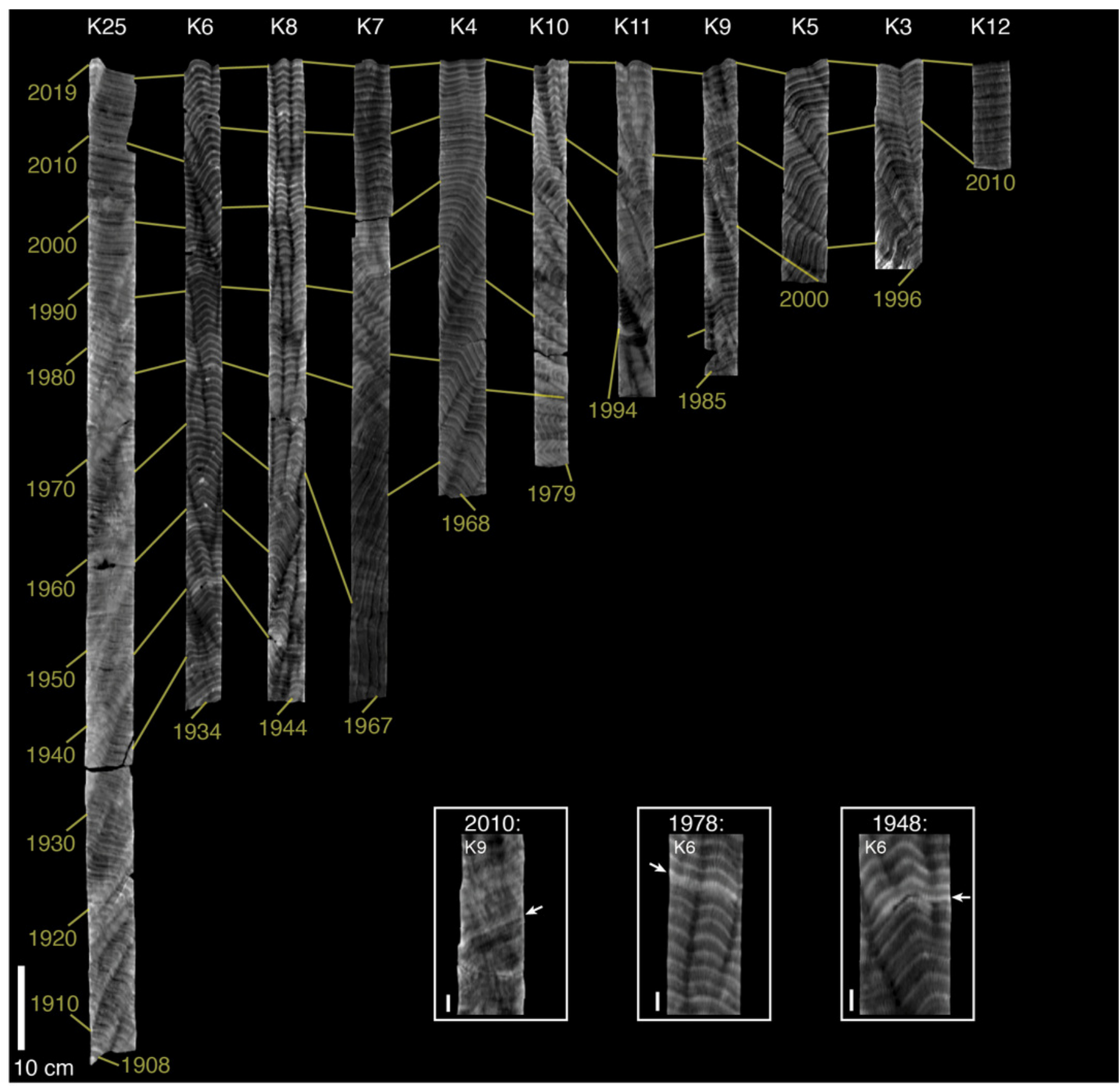




\section{Figure 4}

Probabilities of finding the observed number of stress bands or fewer per year.

The results are shown separately for Abu Shosha (A) and outside of Abu Shosha (B), for bleaching events affecting 1/3 (blue) or 8/11 (red) Porites corals. The dashed black lines indicate a probability of 0.05 . Time periods covered by only a single core are shown in lighter shading. Bars lower (higher) than the 0.05 line indicate that we can (cannot) conclude with $95 \%$ confidence that there are fewer observed stress bands in that year than expected for the given proportion (1/3 or 8/11) of corals affected by a hypothetical event. (C) Simple proportion of corals with stress bands each year, displayed separately for Abu Shosha and outside of Abu Shosha, and with years covered by three or less total cores displayed in lighter shading. 

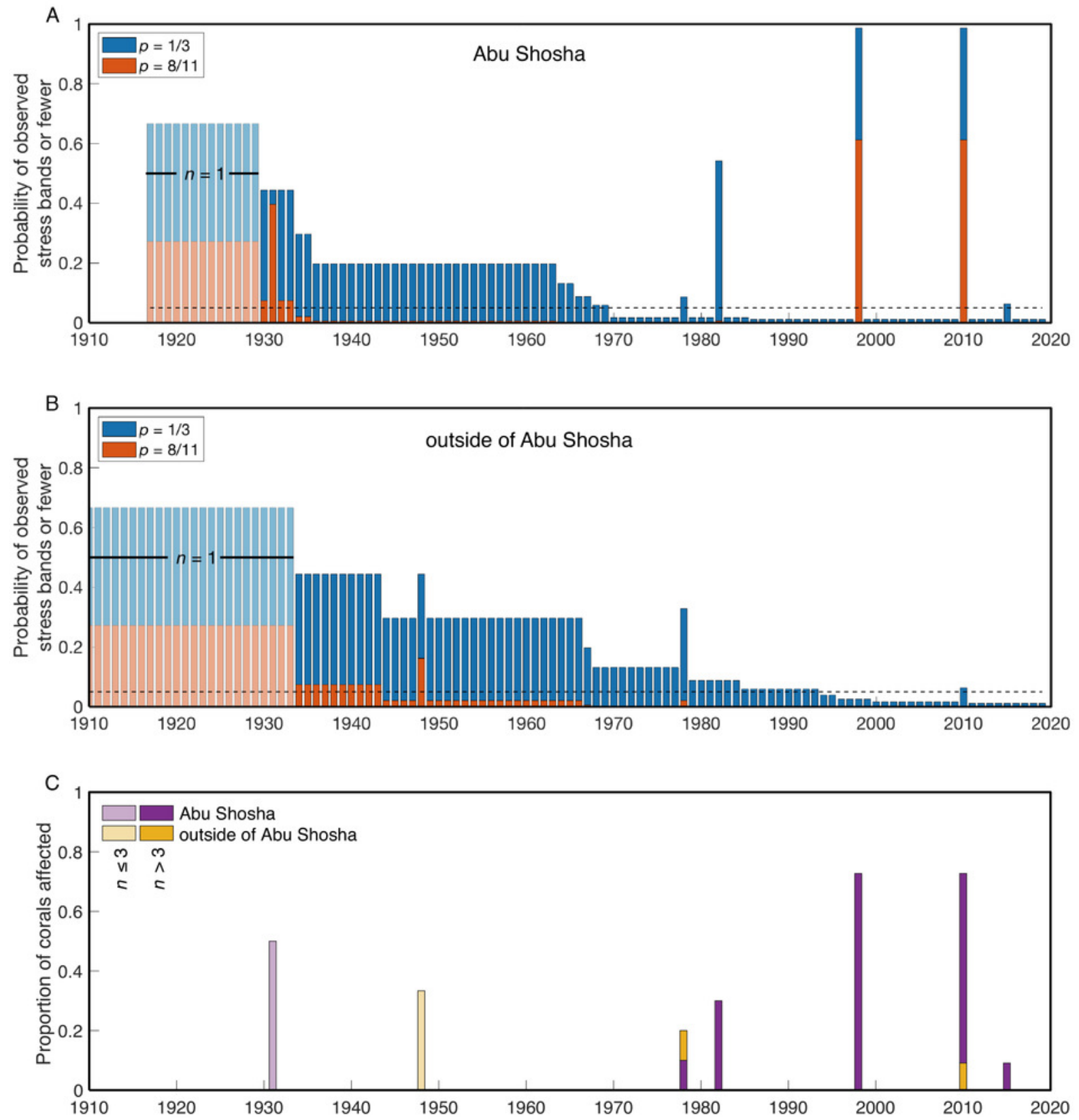
Figure 5

Heat stress histories of the Saudi Arabian central Red Sea.

Maximum annual DHW are shown for the monthly HadISST (maroon) and ERSSTv5 (mustard) datasets (A), and the daily OI-SSTV2 (brown) and CRW (turquoise) datasets (B). Years with stress bands are labelled. Inset boxes show the correlations between maximum annual DHW calculated from the two pairs of datasets.

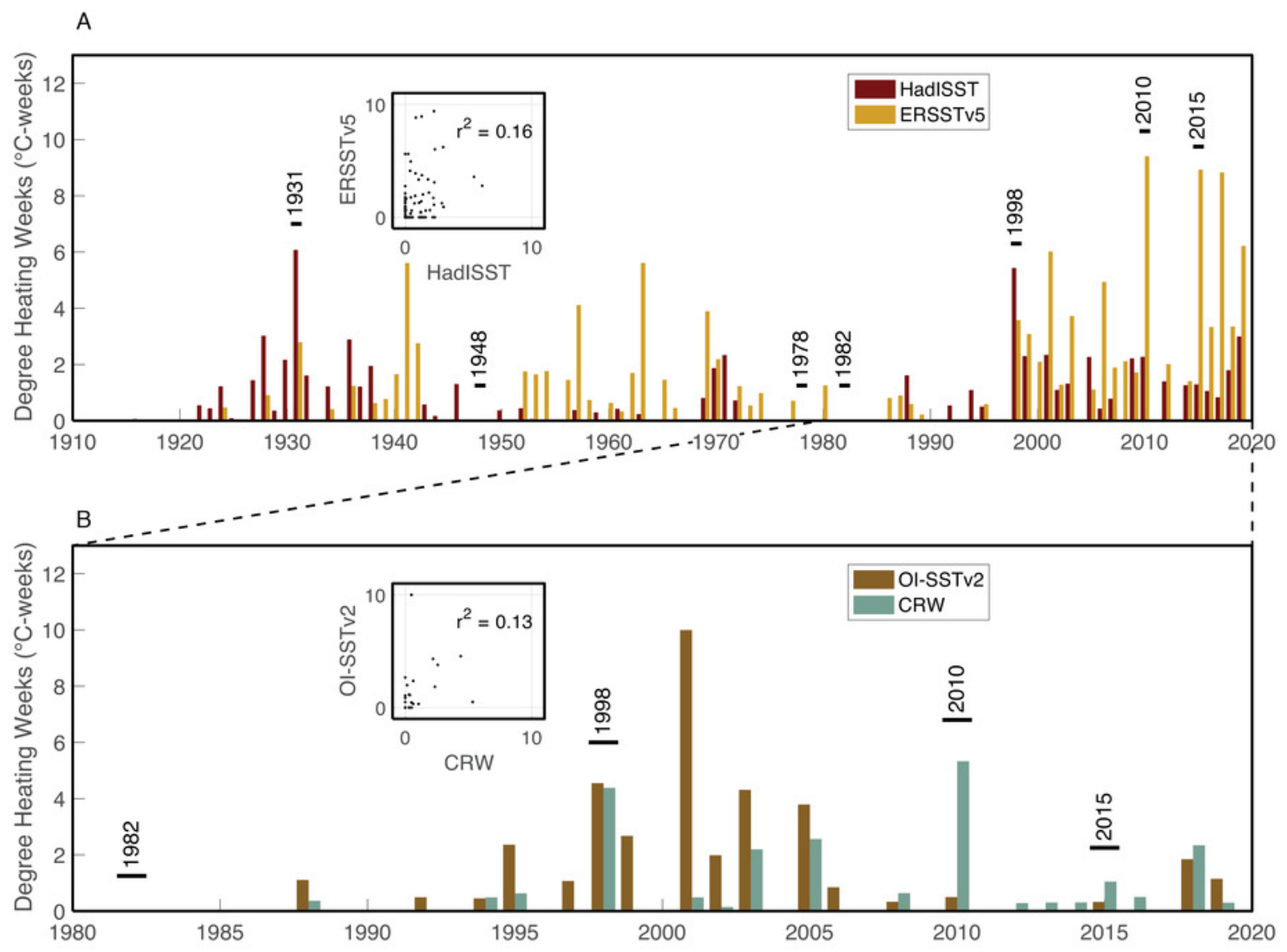




\section{Figure 6}

Spatial distribution of maximum DHW in 2010 according to CRW.

Black circles indicate Abu Shosha and the sampling location of each core collected outside of Abu Shosha.

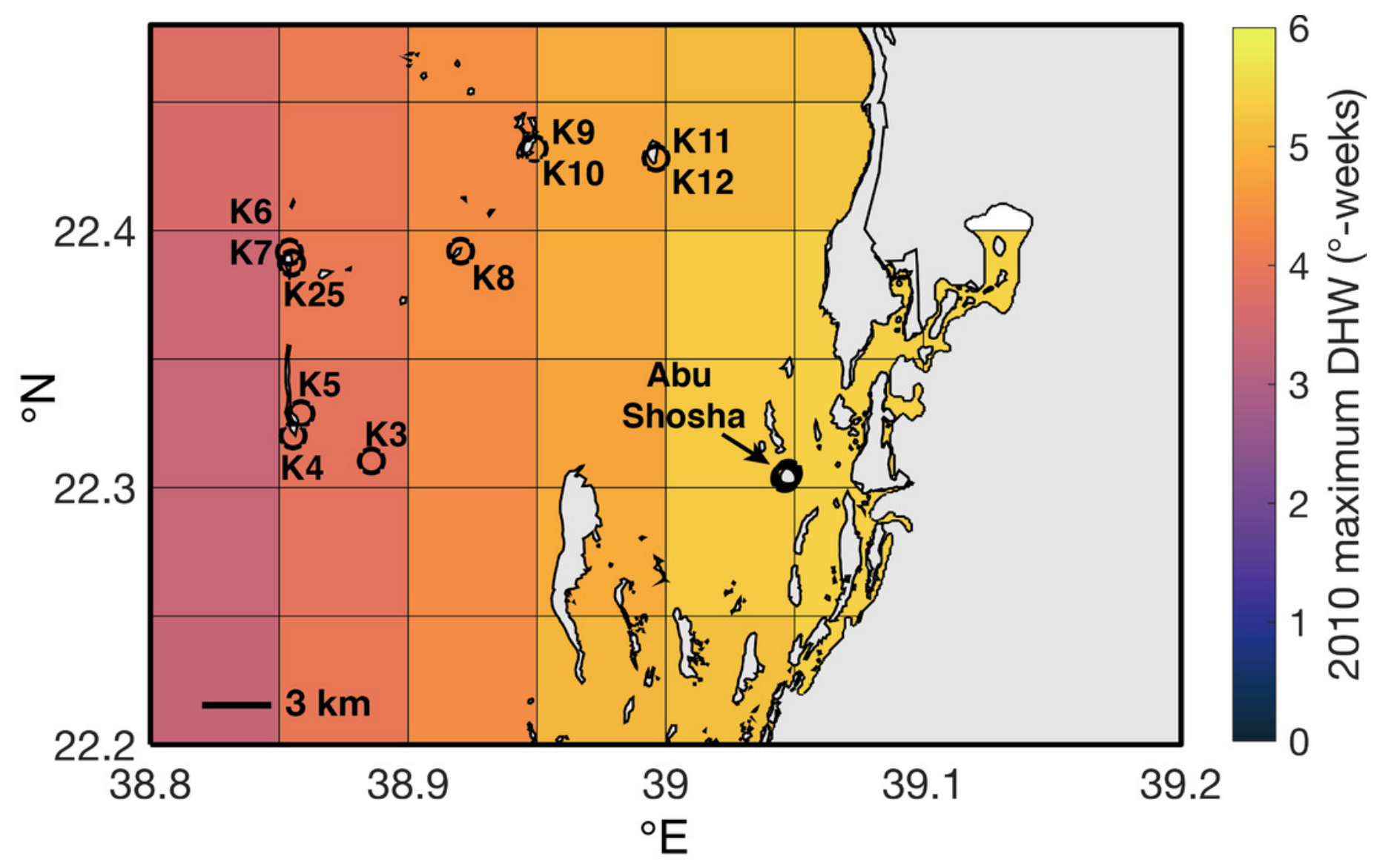




\section{Figure 7}

Historical shipboard SST measurements in the ICOADS database.

(A-C) Locations and numbers of shipboard SST measurements in August and September of 1931, 1982, and 1998. Each measurement is plotted as a semi-transparent gray circle, such that darker gray coloring indicates multiple measurements in the same location. Numbers of measurements ( $n$ ) are displayed for the central Red Sea (the area covered in the maps), and both the HadISST and ERSSTv5 grid-boxes nearest to Abu Shosha. (D) The size of grid-boxes in the OI-SSTV2 and CRW datasets. We use the OI-SSTv2 grid-box that covers Abu Shosha in our calculations, but the next grid-box to the west is also displayed to visualize its relation to shelf and offshore water, and both grid-boxes produce similar results such that the choice of grid-box does not affect our conclusions. 

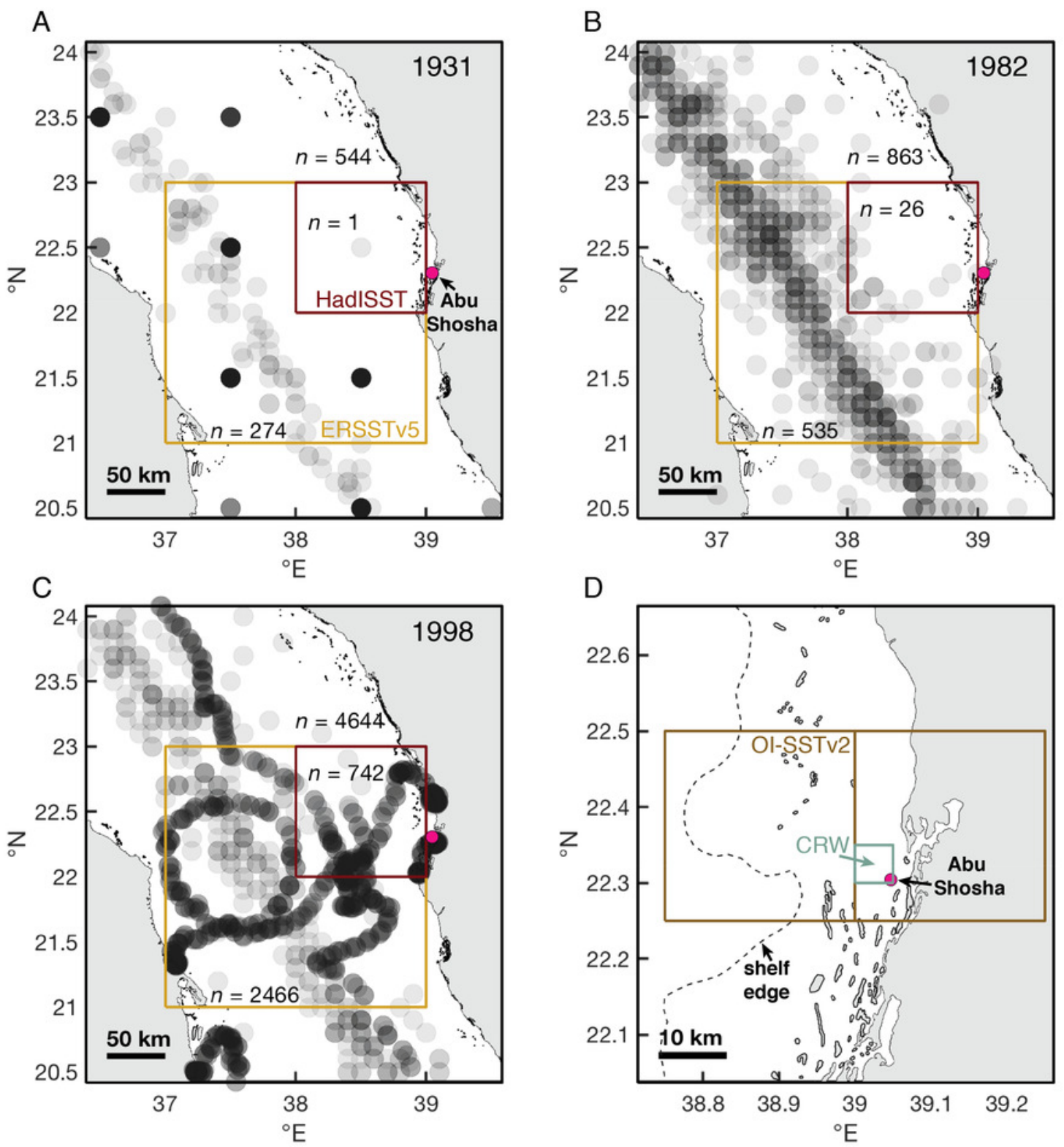
Figure 8

Wind and PAR anomalies near Abu Shosha.

(A) Mean wind speed anomalies for August-September of each year relative to the climatological mean August-September wind speeds of the full time series. Bleaching years are indicated with asterisks. (B) Same as panel (A) but for PAR anomalies.

A

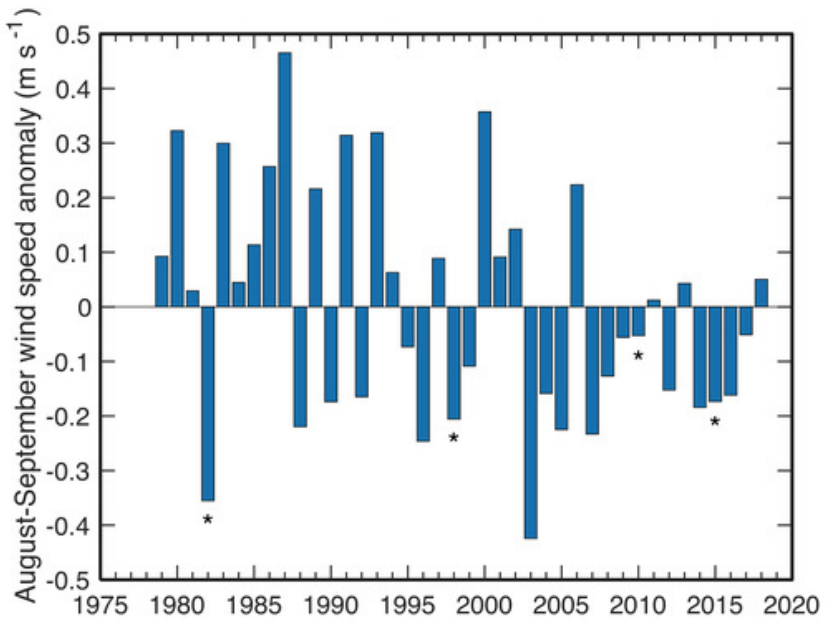

B

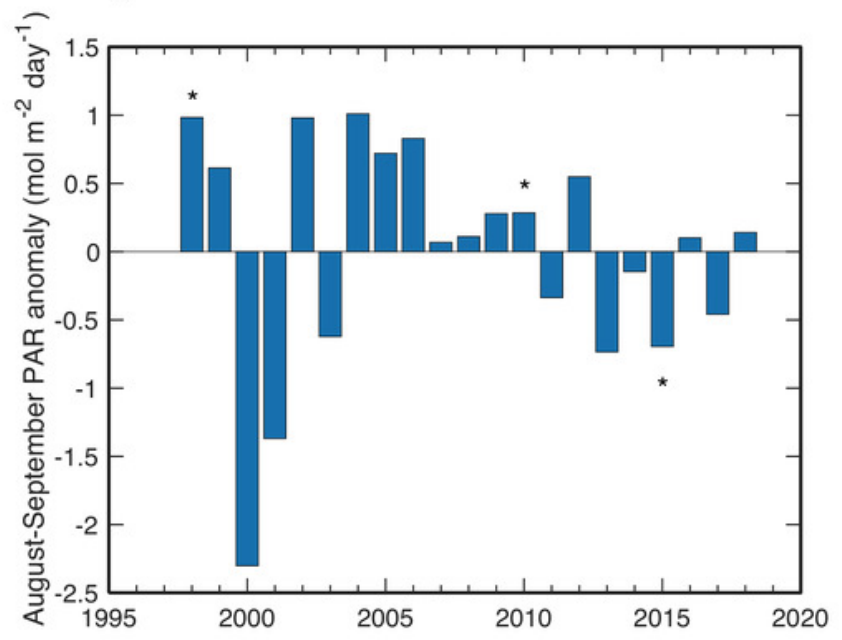

